\title{
An Annulative Approach to Highly Substituted Indoles: Unusual Effect of Phenolic Additives on the Success of the Arylation of Ketone Enolates
}

\author{
Jennifer L. Rutherford, Matthew P. Rainka and Stephen L. Buchwald* \\ Department of Chemistry, Massachusetts Institute of Technology, Cambridge, \\ Massachusetts 02139
}

\section{Supplemental Information}

General Considerations. All palladium-catalyzed reactions were carried out under an argon atmosphere in oven-dried glassware. Toluene was purchased from J. T. Baker in CYCLE-TAINER ${ }^{1}$ solvent delivery kegs, which were purged with argon for 2 hours and purified by passing the toluene through two packed columns of neutral alumina and copper(II) oxide under argon pressure. All other reagents were used as purchased without further purification. 2-Bromo-5-fluoronitrobenzene and 3-chloro-4nitrobenzotrifluoride were purchased from Marshallton Research Laboratories. All other halides and ketones were purchased from Aldrich or Alfa-Aesar. 4-Methoxyphenol was purchased from Acros and phenol was purchased from Aldrich. An aqueous titanium(III) chloride solution, 20\% in 3\% hydrochloric acid, was purchased from Alfa Aesar and each bottle was titrated with potassium bromate prior to use. The solutions were routinely $1.3-1.5 \mathrm{M} \mathrm{TiCl}{ }_{3}$. Potassium phosphate was obtained from Fluka as a granular solid. Other sources of potassium phosphate are powders or hard solid pieces and often resulted in reduced rates when utilized in the reactions. More consistent results could be obtained when the potassium phosphate pieces were ground into a powder, but the current preferred source for potassium phosphate is Fluka. $\mathrm{Pd}_{2} \mathrm{dba}_{3}$ was purchased from Strem Chemical Company. 2-Dicyclohexylphosphino-2 dimethylaminobiphenyl, ${ }^{2}$ 2-di-t-butylphosphino-2 -dimethylaminobiphenyl ${ }^{1}$ and1-(di-t-butylphosphino)-oterphenyl $^{3}$ were synthesized according to literature procedures. 2-Dicyclohexylphosphino-2 -

\footnotetext{
${ }^{1}$ (a) Pangborn, A. B.; Giardello, M. A.; Grubbs, R. H.; Rosen, R. K.; Timmers, F. J. Organometallics 1996, 15, 1518-1520. (b) Alaimo, P. J.; Peters, D. W.; Arnold, J.; Bergman, R. G. J. Chem. Ed. 2001, 78, 64. ${ }^{2}$ Tomori, H.; Fox, J. M.; Buchwald, S. L. J. Org. Chem. 2000, 65, 5334.

${ }^{3}$ Aranyos, A.; Old, D. W.; Kiyomori, A.; Wolfe, J. P.; Sadighi, J. P.; Buchwald, S. L. J. Am. Chem. Soc. 1999, 121, 4369.
} 
dimethylaminobiphenyl and 2-di-t-butylphosphino-2 -dimethylaminobiphenyl are also commercially available from Strem Chemical Company.

Reported yields are the isolated yields of compounds determined to be greater than $95 \%$ pure as determined by proton NMR spectroscopy and gas chromatographic analysis. New compounds were characterized by elemental analysis or high resolution mass spectrometry combined with proton and carbon NMR spectroscopic analysis. Elemental analyses were performed by Atlantic Microlabs, Norcross, GA. IR spectra were obtained on a Perkin Elmer 1600 series FT-IR spectrometer. NMR spectra were recorded on a Varian XL 300 instrument with chemical shifts reported in ppm relative to trimethylsilane or residual deuterated solvent. Gas chromatographic analyses were carred out on a Hewlett Packard 6890 instrument with a FID detector and a HP-1 10m x $0.1 \mathrm{~mm}$ i.d. column.

\section{General Procedure for the One-Pot Synthesis of Indoles: Arylation of Ketones with Ortho-nitro Aryl Halides Followed by Reductive Cyclization.}

The synthesis of all compounds followed this general procedure. Details such as temperature and time are included in Table 1.

To an oven-dried resealable Schlenk tube containing a stir bar, $\mathrm{Pd}_{2} \mathrm{dba}_{3}(0.01 \mathrm{mmol})$, the ligand $(0.04 \mathrm{mmol}), \mathrm{K}_{3} \mathrm{PO}_{4}(2.3 \mathrm{mmol})$, and the phenol $(0.2 \mathrm{mmol})$ were added. If a solid, the ortho-nitro aryl halide $(1.0 \mathrm{mmol})$ was also placed into the tube. The tube was fitted with a rubber septum and was evacuated and backfilled with argon twice. Toluene $(2 \mathrm{~mL})$ and the ketone $(2.2 \mathrm{mmol})$ were syringed into the tube. If a liquid, the ortho-nitro aryl halide $(1.0 \mathrm{mmol})$ was added via syringe to the reaction vessel as well. The tube was sealed with a teflon screw cap and was stirred at the indicated temperature $\left(35-80^{\circ} \mathrm{C}\right)$ for the indicated time when the starting halide was judged to be completely consumed by GC analysis (1526.5h). After allowing the reaction to cool to room temperature, the reaction mixture was extracted with a total of $10 \mathrm{~mL}$ ethyl acetate and $10 \mathrm{~mL}$ water. The separated organic layer was concentrated in vacuo. The material was used, without purification, for the next step.

To a $100 \mathrm{~mL}$ round-bottom flask, aqueous $\mathrm{TiCl}_{3}(16.5 \mathrm{mmol})$, aqueous ammonium acetate $(15$ $\mathrm{mL} ; 6.6 \mathrm{M})$, and ethanol $(5 \mathrm{~mL})$ were added. The flask was fitted with a rubber septum and a needle, connected via tubing to an argon tank, was inserted to provide a constant argon purge. Ethanol $(15 \mathrm{~mL})$ was added to dissolve the crude ketone. If the crude mixture was not completely soluble in ethanol, ethyl acetate $(2-3 \mathrm{~mL})$ was also added. The crude ketone solution was slowly added by syringe to the titanium trichloride solution and the resulting mixture was stirred at room temperature for 15 min (except for the cyclization of 2-isopropylindole, which was stirred at room temperature for $2.5 \mathrm{~h}$ ). 
The reaction mixture was extracted with diethyl ether $(3 \mathrm{X} 25 \mathrm{~mL})$. The combined organic extracts were washed with saturated sodium bicarbonate, followed by brine, dried over sodium sulfate, and concentrated in vacuo. Purification of the crude product was carried out by column chromatography on silica gel.

\section{6-Fluoro-2-phenyl-1H-indole ${ }^{4}$ (Table 1, entry 1).}

The general procedure was followed using phenol. Column chromatography with 1:1 dichloromethane:hexanes resulted in $164 \mathrm{mg}$ (78\%) of the title compound as a white solid: $\mathrm{mp}=180-181$ ${ }^{\circ} \mathrm{C} ;{ }^{1} \mathrm{H}$ NMR (300 MHz, d $\mathrm{d}^{6}$-DMSO) $\delta 11.65(\mathrm{~s}, 1 \mathrm{H}), 7.82(\mathrm{~d}, J=7.4 \mathrm{~Hz}, 2 \mathrm{H}), 7.51(\mathrm{~m}, 1 \mathrm{H}), 7.44(\mathrm{t}, J=7.7$ $\mathrm{Hz}, 2 \mathrm{H}), 7.29(\mathrm{~m}, 1 \mathrm{H}), 7.15$ (d, $J=9.9 \mathrm{~Hz}, 1 \mathrm{H}), 6.9-6.8(\mathrm{~m}, 2 \mathrm{H}) ;{ }^{13} \mathrm{C}$ NMR $\left(75 \mathrm{MHz}, \mathrm{d}^{6}-\mathrm{DMSO}\right) \delta 158.7$ $\left(\mathrm{d}, J_{C-F}=234 \mathrm{~Hz}\right), 138.2\left(\mathrm{~d}, J_{C-F}=3.7 \mathrm{~Hz}\right), 136.8\left(\mathrm{~d}, J_{C-F}=12.6 \mathrm{~Hz}\right), 131.8,128.8,127.3,125.3,124.7$, $120.9\left(\mathrm{~d}, J_{C-F}=10.2 \mathrm{~Hz}\right), 107.8\left(\mathrm{~d}, J_{C-F}=24.4 \mathrm{~Hz}\right), 98.6,97.1\left(\mathrm{~d}, J_{C-F}=25.4 \mathrm{~Hz}\right)$; IR (neat, $\left.\mathrm{cm}^{-1}\right) 3434$, 1593, 1452, 1356, 1225, 842, 813, 759, 734, 689. Anal. Calcd for $\mathrm{C}_{14} \mathrm{H}_{10} \mathrm{NF}$ : C, 79.60; H, 4.77; Found: C, $79.50 ; \mathrm{H}, 4.72$.

\section{6-Fluoro-2-isobutyl-1 $\mathrm{H}$-indole (Table 1, entry 2).}

The general procedure was followed using 4-methoxyphenol. Column chromatography with 1:1 dichloromethane:hexanes with $1 \% \mathrm{NEt}_{3}$ resulted in $120 \mathrm{mg}(64 \%)$ of the title compound as a yellow solid: $\mathrm{mp}=39-41{ }^{\circ} \mathrm{C} ;{ }^{1} \mathrm{H} \mathrm{NMR}\left(300 \mathrm{MHz}, \mathrm{CDCl}_{3}\right) \delta 7.78(\mathrm{~s}, 1 \mathrm{H}), 7.39(\mathrm{~m}, 1 \mathrm{H}), 6.95(\mathrm{~d}, J=9.3 \mathrm{~Hz}, 1 \mathrm{H}), 6.81$ $(\mathrm{m}, 1 \mathrm{H}), 6.18(\mathrm{~s}, 1 \mathrm{H}), 2.58(\mathrm{~d}, J=6.9 \mathrm{~Hz}, 2 \mathrm{H}), 1.95$ (septet, $J=6.9 \mathrm{~Hz}, 1 \mathrm{H}), 0.97(\mathrm{~d}, J=6.6 \mathrm{~Hz}, 6 \mathrm{H}) ;{ }^{13} \mathrm{C}$ $\operatorname{NMR}\left(75 \mathrm{MHz}, \mathrm{CDCl}_{3}\right) \delta 159.3\left(\mathrm{~d}, J_{C-F}=236 \mathrm{~Hz}\right) ; 139.3\left(\mathrm{~d}, J_{C-F}=3.6 \mathrm{~Hz}\right), 135.7\left(\mathrm{~d}, J_{C-F}=12.4 \mathrm{~Hz}\right)$, $125.4,120.3\left(\mathrm{~d}, J_{C-F}=10.0 \mathrm{~Hz}\right), 108.1\left(\mathrm{~d}, J_{C-F}=24.2 \mathrm{~Hz}\right), 100.5,97.0(26.1 \mathrm{~Hz}), 37.9,29.2,22.8$; IR (neat, $\left.\mathrm{cm}^{-1}\right) 3400,2957,1855,1627,1558,1495,1460,1404,1353,1141,840,808,612,591$. Anal. Calcd for $\mathrm{C}_{12} \mathrm{H}_{14} \mathrm{NF}$ : C, 75.36; H, 7.38; Found: C, 75.35; H, 7.32.

\section{2-Phenyl-6-trifluoromethyl- $1 \mathrm{H}$-indole (Table 1 , entry 3 ).}

The general procedure was followed using phenol. Column chromatography with 1:1 dichloromethane:hexanes resulted in $194 \mathrm{mg}(74 \%)$ of the title compound as a white solid: $\mathrm{mp}=174-175$ ${ }^{\circ} \mathrm{C} ;{ }^{1} \mathrm{H}$ NMR (300 MHz, d $\mathrm{d}^{6}$-DMSO) $\delta 12.00(\mathrm{~s}, 1 \mathrm{H}), 7.89(\mathrm{~d}, J=8.0 \mathrm{~Hz}, 2 \mathrm{H}), 7.72(\mathrm{~d}, J=8.3,1 \mathrm{H}), 7.68$ (s, 1H), 7.49 (t, $J=7.7 \mathrm{~Hz}, 2 \mathrm{H}), 7.37(\mathrm{~m}, 1 \mathrm{H}), 7.28(\mathrm{~d}, J=8.3 \mathrm{~Hz}, 1 \mathrm{H}), 7.04(\mathrm{~s}, 1 \mathrm{H}) ;{ }^{13} \mathrm{C}$ NMR $\left(75 \mathrm{MHz}, \mathrm{d}^{6}-\right.$ DMSO) $\delta 140.8,135.8,131.3,131.1,128.9,128.1,125.3\left(\mathrm{q}, J_{C-F}=271 \mathrm{~Hz}\right), 125.3,121.7\left(\mathrm{q}, J_{C-F}=31\right.$ Hz), 120.6, 115.5, 108.4, 98.9; IR (neat, $\mathrm{cm}^{-1}$ ) 3445, 1455, 1345, 1156, 1105, 878, 830, 766, 743, 690. Anal. Calcd for $\mathrm{C}_{15} \mathrm{H}_{10} \mathrm{NF}_{3}$ : C, 68.96; H, 3.86; Found: C, 69.17; H, 3.89 .

\footnotetext{
${ }^{4}$ Rowley, M; Hallett, D. J.; Goodacre, S.; Moyes, C.; Crawforth, J.; Sparey, T. J.; Patel, S.; Marwood, R.; Patel, S; Thomas, S.; Hitzel, L.; O'Connor, D.; Szeto, N.; Castro, J. L.; Hutson, P. H.; MacLeod, A. M. J. Med. Chem. 2001, 44, 1603.
} 


\section{2-Phenyl-5-trifluoromethyl-1H-indole (Table 1, entry 4).}

The general procedure was followed using 4-methoxyphenol. Column chromatography with 1:1 dichloromethane:hexanes resulted in $213 \mathrm{mg}(82 \%)$ of the title compound as a white solid: $\mathrm{mp}=154-155$ ${ }^{\circ} \mathrm{C}$; ${ }^{1} \mathrm{H}$ NMR (300 MHz, d ${ }^{6}$-DMSO) $\delta 12.01(\mathrm{~s}, 1 \mathrm{H}), 7.88(\mathrm{~m}, 3 \mathrm{H}), 7.59$ (d, $\left.J=8.3 \mathrm{~Hz}, 1 \mathrm{H}\right), 7.46$ (t, $J=7.4$ $\mathrm{Hz}, 2 \mathrm{H}), 7.41-7.31$ (m, 2H), $7.02(\mathrm{~s}, 1 \mathrm{H}) ;{ }^{13} \mathrm{C}$ NMR (75 MHz, d $\mathrm{d}^{6}$-DMSO) $\delta$ 139.7, 138.4, 131.3, 131.0, 128.8, 127.9, 127.8, $125.4\left(\mathrm{q}, J_{C-F}=271 \mathrm{~Hz}\right), 120.2\left(\mathrm{q}, J_{C-F}=31 \mathrm{~Hz}\right) 117.7,117.4,111.8$, 99.4; IR (neat, $\mathrm{cm}^{-1}$ ) $3435,1339,1168,1102,1058,896,819,765,747,688$. Anal. Calcd for $\mathrm{C}_{15} \mathrm{H}_{10} \mathrm{NF}_{3}: \mathrm{C}, 68.96 ; \mathrm{H}$, 3.86; Found: C, 68.70; H, 3.71 .

\section{2-Phenyl-1H-indole-6-carbonitrile (Table 1, entry 5).}

The general procedure was followed using phenol. Column chromatography with 9:1 hexanes:ethyl acetate with $1 \%$ added $\mathrm{NEt}_{3}$ gradient to $4: 1$ hexanes:ethyl acetate with $1 \%$ added $\mathrm{NEt}_{3}$ was carried out using dichloromethane as the solvent to load the crude indole onto the column. The purified compound in hexanes and ethyl acetate was washed with $6 \mathrm{M} \mathrm{HCl}(3 \times 15 \mathrm{~mL})$ to remove residual diaryl ether impurity and then washed with saturated sodium bicarbonate followed by brine. The organic extract was dried over sodium sulfate, concentrated in vacuo and resulted in $104 \mathrm{mg}$ (48\%) of the title compound as a tan solid: mp 230-232 ${ }^{\circ} \mathrm{C} ;{ }^{1} \mathrm{H}$ NMR (300 MHz, d ${ }^{6}$-DMSO) $\delta 12.14$ (s, 1H), 7.91 (d $\left.J=7.7 \mathrm{~Hz}, 2 \mathrm{H}\right), 7.83(\mathrm{~s}, 1 \mathrm{H}), 7.68$ $(\mathrm{d}, J=8.3 \mathrm{~Hz}, 1 \mathrm{H}), 7.49$ (t, $J=7.4 \mathrm{~Hz}, 2 \mathrm{H}), 7.4-7.3$ (m, 2H), 7.05 (s, 1H); ${ }^{13} \mathrm{C}$ NMR (75 MHz, d $\left.\mathrm{d}^{6}-\mathrm{DMSO}\right)$ $\delta 141.7,135.7,131.7,130.9,128.9,128.4,125.5,122.0,120.9,120.6,115.7,102.4,99.4$; IR (neat, $\mathrm{cm}^{-1}$ ) $3323,2211,1619,1485,1450,1316,1225,863,816,760,740,683$. HRMS calc : 218.0838; found : 218.0838 .

\section{6-Chloro-2-(2-methoxy-phenyl) -1H-indole (Table 1, entry 6).}

The general procedure was followed using 4-methoxyphenol and $1 \mathrm{~mol} \% \mathrm{Pd}_{2}(\mathrm{dba})_{3}, 4 \mathrm{~mol} \% \mathbf{1 a}$. Column chromatography with 1:1 dichloromethane:hexanes resulted in $166 \mathrm{mg}(64 \%)$ of the title compound as a white solid: mp 144-145 ${ }^{\circ} \mathrm{C} ;{ }^{1} \mathrm{H}$ NMR $\left(300 \mathrm{MHz}, \mathrm{CDCl}_{3}\right) \delta 9.62(\mathrm{~s}, 1 \mathrm{H}), 7.77(\mathrm{~d}, J=7.7 \mathrm{~Hz}, 1 \mathrm{H}), 7.49$ (d, $J=8.5 \mathrm{~Hz}, 1 \mathrm{H}), 7.37(\mathrm{~s}, 1 \mathrm{H}), 7.25(\mathrm{q}, J=8.3 \mathrm{~Hz}, 1 \mathrm{H}), 7.03(\mathrm{~m}, 3 \mathrm{H}), 6.82(\mathrm{~s}, 1 \mathrm{H}), 3.98(\mathrm{~s}, 3 \mathrm{H}) ;{ }^{13} \mathrm{C} \mathrm{NMR}$ $\left(75 \mathrm{MHz}, \mathrm{CDCl}_{3}\right) \delta 155.7,136.9,136.4,129.0,128.3,127.5,126.7,121.7,121.1,120.6,120.2,112.0$, 110.9, 99.9, 56.1; IR (neat, $\mathrm{cm}^{-1}$ ) 3441, 1581, 1534, 1465, 1436, 1352, 1210, 1266, 1240, 1190, 1126, 1059, 1025, 922, 812, 752. Anal. Calcd for $\mathrm{C}_{15} \mathrm{H}_{12} \mathrm{NOCl}$ : C, 69.91; H, 4.69; Found: $\mathrm{C}, 69.80$; H, 4.58 .

\section{2-Butyl-6-methoxy-1H-indole (Table 1, entry 7).}

The general procedure was followed using 4-methoxyphenol. Column chromatography with 1:1 dichloromethane:hexanes resulted in $138 \mathrm{mg}(68 \%)$ of the title compound as a cream-colored solid: $\mathrm{mp}=$ 80-82 ${ }^{\circ} \mathrm{C} ;{ }^{1} \mathrm{H}$ NMR $\left(300 \mathrm{MHz}, \mathrm{CDCl}_{3}\right) \delta 7.70(\mathrm{~s}, 1 \mathrm{H}), 7.36(\mathrm{~d}, J=8.5 \mathrm{~Hz}, 1 \mathrm{H}), 6.8-6.7(\mathrm{~m}, 2 \mathrm{H}), 6.13(\mathrm{~s}$, $1 \mathrm{H}$ ), 3.81 (s, 3H), 2.69 (t, $J=7.4 \mathrm{~Hz}, 2 \mathrm{H}$ ), 1.66 (quintet, $J=7.2 \mathrm{~Hz}, 2 \mathrm{H}$ ), 1.40 (sextet, $J=7.4 \mathrm{~Hz}, 2 \mathrm{H}$ ), 0.94 $(\mathrm{t}, J=7.4 \mathrm{~Hz}, 3 \mathrm{H}) ;{ }^{13} \mathrm{C} \mathrm{NMR}\left(75 \mathrm{MHz}, \mathrm{CDCl}_{3}\right) \delta 155.6,138.9,136.5,123.2,120.3,109.1,99.2,94.6,56.0$, 
31.6, 28.2, 22.7, 14.2; IR (neat, $\mathrm{cm}^{-1}$ ) 3384, 2923, 1626, 1552, 1458, 1403, 1310, 1160, 1028, 812, 736, 620. Anal. Calcd for $\mathrm{C}_{13} \mathrm{H}_{17} \mathrm{NO}$ : C, 76.81; H, 8.43; Found: C, 76.79, 8.26.

\section{2-Butyl-1H-indole-6-carboxylic acid ethyl ester (Table 1, entry 8).}

The general procedure was followed using phenol. Column chromatography with 8:1 toluene:ethyl acetate with $1 \% \mathrm{NEt}_{3}$ was carried out. The purified compound in toluene and ethyl acetate was washed with $6 \mathrm{M}$ $\mathrm{HCl}(3 \times 15 \mathrm{~mL})$ to remove residual diaryl ether impurity and then washed with saturated sodium bicarbonate followed by brine. The organic extract was dried over sodium sulfate, concentrated in vacuo and resulted in $151 \mathrm{mg}(61 \%)$ of the title compound as a yellow solid: $\mathrm{mp}=94-95{ }^{\circ} \mathrm{C} ;{ }^{1} \mathrm{H}$ NMR $(300 \mathrm{MHz}$, $\left.\mathrm{CDCl}_{3}\right) \delta 8.34(\mathrm{~s}, 1 \mathrm{H}), 8.10(\mathrm{~s}, 1 \mathrm{H}), 7.79(\mathrm{~d}, J=8.3 \mathrm{~Hz}, 1 \mathrm{H}), 7.53$ (d, $\left.J=8.3 \mathrm{~Hz}, 1 \mathrm{H}\right), 6.30(\mathrm{~s}, 1 \mathrm{H}), 4.41$ (q, $J=7.2 \mathrm{~Hz}, 2 \mathrm{H}$ ), 2.81 (t, $J=7.7 \mathrm{~Hz}, 2 \mathrm{H}), 1.75$ (quintet, $J=8.0 \mathrm{~Hz}, 2 \mathrm{H}), 1.44(\mathrm{~m}, 5 \mathrm{H}), 0.98$ (t, $J=7.4 \mathrm{~Hz}$, $3 \mathrm{H}) ;{ }^{13} \mathrm{C}$ NMR $\left(75 \mathrm{MHz}, \mathrm{CDCl}_{3}\right) \delta 168.1,144.1,135.2,132.8,122.6,120.8,119.1,112.8,100.1,60.9$, 31.3, 28.4, 22.7, 14.8, 14.2; IR (neat, $\mathrm{cm}^{-1}$ ) 3317, 2931, 1684, 1537, 1310, 1223, 782, 743. Anal. Calcd for $\mathrm{C}_{15} \mathrm{H}_{19} \mathrm{NO}_{2}$ : C, 73.44; H, 7.81; Found: C, 73.30; H, 7.73.

\section{4-Methyl-2-phenyl-1H-indole (Table 1, entry 9).}

The general procedure was followed using 2,6-dimethoxyphenol, 2.0 equiv of ketone, and $\mathbf{1 c}$ used as ligand. Column chromatography with 1:1 dichloromethane:hexanes resulted in $142 \mathrm{mg}(69 \%)$ of the title compound as a white solid: $\mathrm{mp}=102-103{ }^{\circ} \mathrm{C} ;{ }^{1} \mathrm{H}$ NMR $\left(300 \mathrm{MHz}, \mathrm{CDCl}_{3}\right) \delta 8.20(\mathrm{~s}, 1 \mathrm{H}), 7.59(\mathrm{~d}, J=7.2$ $\mathrm{Hz}, 2 \mathrm{H}), 7.38$ (t, $J=7.2 \mathrm{~Hz}, 2 \mathrm{H}), 7.27(\mathrm{~m}, 1 \mathrm{H}), 7.18(\mathrm{~d}, J=8.0 \mathrm{~Hz}, 1 \mathrm{H}), 7.08$ (t, $J=7.4 \mathrm{~Hz}, 1 \mathrm{H}), 6.90$ (d, $J$ $=7.2 \mathrm{~Hz}, 1 \mathrm{H}), 2.56(\mathrm{~s}, 3 \mathrm{H}) ;{ }^{13} \mathrm{C} \mathrm{NMR}\left(75 \mathrm{MHz}, \mathrm{CDCl}_{3}\right) \delta 137.3,136.5,132.5,130.3,129.2,129.1,127.7$, 125.1, 122.6, 120.5, 108.6, 98.7, 19.1; IR (neat, $\mathrm{cm}^{-1}$ ) 3417, 1602, 1488, 1450, 1356, 1338, 1296, 1157, 759, 690. Anal. Calcd for $\mathrm{C}_{15} \mathrm{H}_{13} \mathrm{~N}$ : C, 86.92; H, 6.32; Found: C, 86.74; H, 6.37.

\section{4-(1H-Indol-2-yl)-butyric acid ethyl ester (Table 1, entry 10).}

The general procedure was followed using 4-methoxyphenol. Column chromatography with 8:1 toluene:ethyl acetate resulted in $163 \mathrm{mg}(70 \%)$ of the title compound as a yellow solid: $\mathrm{mp} 91-92{ }^{\circ} \mathrm{C} ;{ }^{1} \mathrm{H}$ NMR (300 MHz, $\left.\mathrm{CDCl}_{3}\right) \delta 8.05(\mathrm{~s}, 1 \mathrm{H}), 7.50(\mathrm{~d}, J=7.4 \mathrm{~Hz}, 1 \mathrm{H}), 7.24(\mathrm{~d}, J=8.0 \mathrm{~Hz}, 1 \mathrm{H}), 7.06$ (quintet, $J$ $=7.1 \mathrm{~Hz}, 2 \mathrm{H}), 6.22(\mathrm{~s}, 1 \mathrm{H}), 4.16(\mathrm{q}, J=7.2 \mathrm{~Hz}, 2 \mathrm{H}), 2.76(\mathrm{t}, J=7.2 \mathrm{~Hz}, 2 \mathrm{H}), 2.36(\mathrm{t}, J=7.2 \mathrm{~Hz}, 2 \mathrm{H}), 2.01$ (t, $J=7.2 \mathrm{~Hz}, 2 \mathrm{H}), 1.24(\mathrm{t}, J=7.2 \mathrm{~Hz}, 3 \mathrm{H}) ;{ }^{13} \mathrm{C} \mathrm{NMR}\left(75 \mathrm{MHz}, \mathrm{CDCl}_{3}\right) \delta 173.6,138.5,136.0,128.7$, 121.2, 119.9, 119.7, 110.5, 100.1, 60.7, 33.7, 27.6, 24.9, 14.6; IR (neat, $\mathrm{cm}^{-1}$ ) 3351, 2982, 2950, 1719, 1464, 1320, 1292, 1264, 1235, 1185, 1011, 770, 745, 669. Anal. Calcd for $\mathrm{C}_{14} \mathrm{H}_{17} \mathrm{NO}_{2}$ : C, 72.70; H, 7.41; Found: C, 72.56; H, 7.46 .

\section{1,2,3,4-Tetrahydro-cyclopenta[b]indole-6-carboxylic acid ethyl ester (Table 1, entry 11).}

The general procedure was followed using phenol and 6.0 equiv of ketone. Column chromatography with 8:1 toluene:ethyl acetate with methylene chloride to load the crude indole onto the column was carried out. 
The purified compound in the toluene / ethyl acetate mixture was washed with $6 \mathrm{M} \mathrm{HCl}(3 \mathrm{x} 15 \mathrm{~mL})$ to remove residual diaryl ether impurity (from reaction of the phenol with the aryl halide) which co-eluted with the desired compound, and then washed with saturated sodium bicarbonate followed by brine. The organic extract was dried over sodium sulfate, concentrated in vacuo and resulted in $137 \mathrm{mg}(60 \%)$ of the title compound as a tan solid: $\mathrm{mp}=155-158{ }^{\circ} \mathrm{C} ;{ }^{1} \mathrm{H} \mathrm{NMR}\left(300 \mathrm{MHz}, \mathrm{CDCl}_{3}\right) \delta 8.31(\mathrm{~s}, 1 \mathrm{H}), 8.04(\mathrm{~s}, 1 \mathrm{H})$, $7.77(\mathrm{~d}, J=8.3 \mathrm{~Hz}, 1 \mathrm{H}), 7.39(\mathrm{~d}, J=8.3 \mathrm{~Hz}, 1 \mathrm{H}), 4.38(\mathrm{~d}, J=7.2 \mathrm{~Hz}, 2 \mathrm{H}), 2.84(\mathrm{~m}, 4 \mathrm{H}), 2.55$ (m, $2 \mathrm{H})$, $1.41(\mathrm{t}, J=7.2 \mathrm{~Hz}, 3 \mathrm{H}) ;{ }^{13} \mathrm{C} \mathrm{NMR}\left(75 \mathrm{MHz}, \mathrm{CDCl}_{3}\right) \delta 168.1,148.0,140.3,128.2,122.1,120.8,120.3$, 117.8, 113.6, 60.8, 28.9, 26.2, 24.5, 14.8; IR $\left(\mathrm{CDCl}_{3}, \mathrm{~cm}^{-1}\right)$ 3736, 3424, 1700, 1686, 1312, 1285, 1090, 1005. HRMS calc : 229.1097 ; found : 229.1105 .

\section{2-Isopropyl-1H-indole ${ }^{5}$ (Table 1, entry 12)}

The general procedure was followed using 4-methoxyphenol and 1.2 equiv of ketone. Column chromatography with 1:1 dichloromethane:hexanes resulted in $104 \mathrm{mg}(66 \%)$ of the title compound as a white solid with characterization consistent with literature reported values: $\mathrm{mp}=72-73{ }^{\circ} \mathrm{C}$.

\section{2-Butyl-5-fluoro-6-methyl-1H-indole (Table 1, entry 13).}

The general procedure was followed using 4-methoxyphenol. Column chromatography over silica gel eluting with 5:95 ethyl acetate:hexanes gave $144 \mathrm{mg}(70 \%)$ of the title compound as a yellow solid: $\mathrm{mp}=$ 109-111 ${ }^{\circ} \mathrm{C} ;{ }^{1} \mathrm{H} \mathrm{NMR}\left(\mathrm{CDCl}_{3}, 300 \mathrm{MHz}\right) \delta 7.71(\mathrm{bs}, 1 \mathrm{H}), 7.13(\mathrm{~m}, 1 \mathrm{H}), 7.04(\mathrm{~m}, 1 \mathrm{H}), 6.17(\mathrm{~m}, 1 \mathrm{H}), 2.75(\mathrm{t}$, $J=7.4 \mathrm{~Hz}, 2 \mathrm{H}), 2.38(\mathrm{~s}, 3 \mathrm{H}), 1.68$ (quint, $J=7.4 \mathrm{~Hz}, 2 \mathrm{H}), 1.44$ (hext, $J=7.4 \mathrm{~Hz}, 2 \mathrm{H}), 1.01$ (t, $J=7.4 \mathrm{~Hz}$, $3 \mathrm{H}) ;{ }^{13} \mathrm{C} \mathrm{NMR}\left(\mathrm{CDCl}_{3}, 75 \mathrm{MHz}\right)$ 8155.3, 140.9, 132.4, 127.3, $118.5(\mathrm{~m}), 111.67(\mathrm{~m}), 104.3$ (m), 99.5, 31.5, 28.3, 22.7, 15.6, 14.2; IR $\left(\mathrm{CDCl}_{3}, \mathrm{~cm}^{-1}\right)$ 3473, 2960, 2931, 1466, 1175, 1092, 859; Anal. Calcd for $\mathrm{C}_{13} \mathrm{H}_{16} \mathrm{FN}$ : C, 76.06; H, 7.86; Found: C, 76.08; H, 7.86.

\section{2-Butyl-5,6-dimethoxy-1H-indole (Table 1, entry 14).}

The general procedure was followed using 4-methoxyphenol. Column chromatography over silica gel eluting with 1:5 ethyl acetate:hexanes gave $175 \mathrm{mg}(75 \%)$ of the title compound as a bright yellow oil: ${ }^{1} \mathrm{H}$ $\mathrm{NMR}\left(\mathrm{CDCl}_{3}, 300 \mathrm{MHz}\right) \delta 7.96$ (bs, 1H), 7.06 (s, 1H), 6.70 (s, 1H), $6.16(\mathrm{~s}, 1 \mathrm{H}), 3.93$ (s, 3H), 3.83 (s, 3H), $2.71(\mathrm{t}, J=7.4 \mathrm{~Hz}, 2 \mathrm{H}), 1.71$ (quint, $J=7.4 \mathrm{~Hz}, 2 \mathrm{H}$ ), 1.44 (hext, $J=7.4 \mathrm{~Hz}, 2 \mathrm{H}$ ), 1.00 (t, $J=7.4 \mathrm{~Hz}, 3 \mathrm{H}$ );

${ }^{13} \mathrm{C} \mathrm{NMR}\left(\mathrm{CDCl}_{3}, 75 \mathrm{MHz}\right) \delta 145.8,144.5,138.7 .130 .0,121.4,101.9,98.7,94.5,56.4,56.2,31.6,28.1$, 22.6, 14.1; IR $\left(\mathrm{CDCl}_{3}, \mathrm{~cm}^{-1}\right)$ 3736, 3477, 2960, 2937, 1486, 1314, 1200, 1123, 1009, 841, 725; Anal. Calcd for $\mathrm{C}_{14} \mathrm{H}_{19} \mathrm{NO}_{2}$ : C, 72.07; H, 8.21; Found: C, 71.94; H, 8.25.

General Procedure for the Synthesis of 2,3-Substituted Indoles : Arylation of Ketones with Orthonitro Aryl Halides Followed by Alkylation, then Reductive Cyclization. 
Procedure A. Details such as temperature and time are included in Table 2.

To an oven-dried resealable Schlenk tube containing a stir bar was added $\mathrm{Pd}_{2} \mathrm{dba}_{3}(0.01 \mathrm{mmol})$, the ligand $(0.04 \mathrm{mmol}), \mathrm{K}_{3} \mathrm{PO}_{4}(2.3 \mathrm{mmol})$, and 4-methoxyphenol $(0.2 \mathrm{mmol})$. If a solid, the ortho-nitro aryl halide $(1.0 \mathrm{mmol})$ was also placed into the tube. The tube was fitted with a rubber septum and was evacuated and backfilled with argon twice. Toluene $(2 \mathrm{~mL})$ and the ketone $(2.0 \mathrm{mmol})$ were added via syringe to the tube. If a liquid, the ortho-nitro aryl halide $(1.0 \mathrm{mmol})$ was added by syringe to the reaction vessel as well. The tube was sealed with a teflon screw cap and was stirred at the indicated temperature $\left(35-50^{\circ} \mathrm{C}\right)$ for the indicated time when the starting halide was judged to be completely consumed by GC analysis. ( $24 \mathrm{~h}$ ) The reaction mixture was allowed to cool to room temperature, then diluted with $1: 1$ ethyl acetate $: 2 \mathrm{~N} \mathrm{NaOH}$. The layers were separated and the aqueous layer was extracted two times with ethyl acetate. The combined organic layers were washed with brine, dried over magnesium sulfate, filtered, and concentrated. The residue was then dissolved in THF $(2 \mathrm{~mL})$ and the electrophile $(1.1 \mathrm{mmol})$ was added. This solution was then added to a stirring suspension of sodium hydride $(52 \mathrm{mg}, 1.3 \mathrm{mmol})$ in THF $(2 \mathrm{~mL})$. The reaction was allowed to stir at room temperature for two $\mathrm{h}$, and then concentrated to dryness. The residue was then carefully dissolved in ethanol (4 mL) (this will also quench any residual $\mathrm{NaH}$ ) and slowly added to a stirring solution of $\mathrm{TiCl}_{3}(13 \mathrm{~mL}, 16 \mathrm{mmol})$ and ammonium acetate $(16 \mathrm{~mL}, 6 \mathrm{M})$ in ethanol $(16 \mathrm{~mL})$. When the addition was complete, the reaction mixture was allowed to stir at room temperature for an additional fifteen min, and was then diluted with diethyl ether. The layers were separated and the aqueous layer was extracted three times with diethyl ether. The combined organic layers were then carefully washed with saturated aqueous sodium bicarbonate, brine, dried over magnesium sulfate, filtered and concentrated. The residue was then purified by flash chromatography over silica gel to give the desired indole product.

\section{General Procedure for the Synthesis of 2,3-Substituted Indoles : Arylation of Ketones with Ortho- nitro Aryl Halides Followed by Alkylation, then Reductive Cyclization.}

Procedure B. Details such as temperature and time are included in the Table 2.

The method of procedure A was followed to prepare the arylated ketone. At this point, under a positive pressure of argon, the screw cap was removed and THF $(1 \mathrm{~mL})$ and methyl iodide $(94 \mu \mathrm{L}, 1.5$ mmol) were added. The screw cap was replaced and the reaction flask was placed back in a $50{ }^{\circ} \mathrm{C}$ oil bath and left for $18 \mathrm{~h}$. The reaction mixture was allowed to cool to room temperature, then diluted with a $1: 1$ mixture of ethyl acetate : water. The layers were separated and the aqueous layer was extracted two times with ethyl acetate. The combined organic layers were washed with brine, dried over magnesium sulfate, filtered, and concentrated. This residue was then dissolved in ethanol $(5 \mathrm{~mL})$ and slowly added to a stirring

${ }^{5}$ Smith, A. B. III; Visnick, M.; Haseltine, J. N.; Sprengler, P. A. Tetrahedron, 1986, 42(11), 2957. 
solution of $\mathrm{TiCl}_{3}(10 \mathrm{~mL}, 14 \mathrm{mmol})$ and ammonium acetate $(11 \mathrm{~mL}, 6 \mathrm{M})$ in ethanol $(10 \mathrm{~mL})$. When addition was complete, the reaction mixture was allowed to stir at room temperature for an additional fifteen min, then the reaction mixture was diluted with diethyl ether. The layers were separated and the aqueous layer was extracted two times with diethyl ether. The combined organic layers were then carefully washed with saturated aqueous sodium bicarbonate, brine, dried over magnesium sulfate, filtered and concentrated. The residue was then purified by flash chromatography over silica gel to give the desired indole product.

\section{3-Methyl-2-phenyl-1H-indole-6-carboxylic acid ethyl ester (Table 2, entry 1).}

General procedure A was followed at $50 ; \mathrm{C}$. Column chromatography over silica gel eluting with 1:1:8 ethyl acetate:dichloromethane:hexanes gave $167 \mathrm{mg}(60 \%)$ of the title compound as a light yellow solid: $\mathrm{mp}=133-135{ }^{\circ} \mathrm{C} ;{ }^{1} \mathrm{H}$ NMR $\left(\mathrm{CDCl}_{3}, 300 \mathrm{MHz}\right) \delta 8.43(\mathrm{bs}, 1 \mathrm{H}), 8.17(\mathrm{~m}, 1 \mathrm{H}), 7.85(\mathrm{~m}, 1 \mathrm{H}), 7.62(\mathrm{~m}, 3 \mathrm{H})$, $7.51(\mathrm{~m}, 2 \mathrm{H}), 7.41(\mathrm{~m}, 1 \mathrm{H}), 4.42(\mathrm{q}, J=7.2 \mathrm{~Hz}, 2 \mathrm{H}), 2.50(\mathrm{~s}, 3 \mathrm{H}), 1.45(\mathrm{t}, J=7.2 \mathrm{~Hz}, 3 \mathrm{H}) ;{ }^{13} \mathrm{C} \mathrm{NMR}$ $\left(\mathrm{CDCl}_{3}, 75 \mathrm{MHz}\right) \delta 167.8,137.5,135.1,133.5,132.7,129.0,128.0,124.0,120.7,118.5,113.1,109.2,99.9$, 61.0, 14.8, 10.0; IR $\left(\mathrm{CDCl}_{3}, \mathrm{~cm}^{-1}\right) 3465,2981,1698,1320,1285,1216,1096,770$; Anal. Calcd for $\mathrm{C}_{18} \mathrm{H}_{17} \mathrm{NO}_{2}$ : C, 77.40; H, 6.13; Found: C, 77.09; H, 6.04.

\section{3-Methoxycarbonylmethyl-2-methyl-1 $H$-indole-6-carboxylic acid ethyl ester (Table 2, entry 2).}

General procedure $\mathrm{A}$ was followed at $35 \mathrm{i} \mathrm{C}$ with 6.0 equiv of ketone. Column chromatography over silica gel eluting with 1:4 ethyl acetate:hexanes gave $188 \mathrm{mg}(68 \%)$ of the title compound as a yellow solid: $\mathrm{mp}=$ $107-110{ }^{\circ} \mathrm{C} ;{ }^{1} \mathrm{H}$ NMR $\left(\mathrm{CDCl}_{3}, 300 \mathrm{MHz}\right) \delta 8.34(\mathrm{bs}, 1 \mathrm{H}), 8.03(\mathrm{~m}, 1 \mathrm{H}), 7.80(\mathrm{~m}, 1 \mathrm{H}), 7.51(\mathrm{~m}, 1 \mathrm{H}), 4.41(\mathrm{q}$, $J=7.2 \mathrm{~Hz}, 2 \mathrm{H}), 3.72(\mathrm{~s}, 2 \mathrm{H}), 3.70(\mathrm{~s}, 3 \mathrm{H}), 2.45(\mathrm{~s}, 3 \mathrm{H}), 1.44(\mathrm{t}, J=7.2 \mathrm{HZ}, 3 \mathrm{H}) ;{ }^{13} \mathrm{C} \mathrm{NMR}\left(\mathrm{CDCl}_{3}, 75\right.$ MHz) $\delta 172.3,167.9,136.7,134.4,132.1,123.2,120.9,117.5,112.7,105.3,60.9,52.3,30.3,14.8,12.3$; IR $\left(\mathrm{CDCl}_{3}, \mathrm{~cm}^{-1}\right) 3751,3651,1735,1698,1314,1301,1270,1208,1021$; Anal. Calcd for $\mathrm{C}_{15} \mathrm{H}_{17} \mathrm{NO}_{4}$ : C, 65.44; H, 6.22; Found: C, 65.49; H, 6.29.

\section{(5,6-Dimethoxy-2-phenyl-1H-indol-3-yl)-acetic acid methyl ester (Table 2, entry 3).}

General procedure A was followed at $50_{i} \mathrm{C}$. Column chromatography over silica gel eluting with $1: 3$ ethyl acetate:hexanes gave $230 \mathrm{mg}$ (70\%) of the title compound as a yellow solid: $\mathrm{mp}=43-45{ }^{\circ} \mathrm{C} ;{ }^{1} \mathrm{H} \mathrm{NMR}$ $\left(\mathrm{CDCl}_{3}, 300 \mathrm{MHz}\right) \delta 8.1(\mathrm{bs}, 1 \mathrm{H}), 7.61(\mathrm{~m}, 2 \mathrm{H}), 7.46(\mathrm{~m}, 2 \mathrm{H}), 7.39(\mathrm{~m}, 1 \mathrm{H}), 7.11(\mathrm{~s}, 1 \mathrm{H}), 6.89(\mathrm{~s}, 1 \mathrm{H}), 3.97$ (s, 3H), 3.92 (s, 3H), 3.84 (s, 2H), 3.75 (s, 3H); ${ }^{13} \mathrm{C}$ NMR $\left(\mathrm{CDCl}_{3}, 75 \mathrm{MHz}\right)$ 8172.7, 147.5, 145.3, 134.8, 132.7, 130.2, 129.0, 127.9, 127.7, 121.9. 105.4, 101.0, 94.5, 56.6, 56.4, 52.3, 31.4; IR $\left(\mathrm{CDCl}_{3}, \mathrm{~cm}^{-1}\right) 3724$, $3465,2956,1733,1484,1341,1245,1216,1160,1003$, 700; HRMS calc : 325.1314 ; found : 325.1295 .

\section{5,6-Dimethoxy-3-methyl-2-phenyl-1 $H$-indole (Table 2, entry4).}

General procedure B was followed at $50_{i} \mathrm{C}$. Column chromatography over silica gel eluting with 1:9 ethyl acetate:hexanes gave $212 \mathrm{mg}(79 \%)$ of the title compound as a yellow solid: $\mathrm{mp}=157-158{ }^{\circ} \mathrm{C} ;{ }^{1} \mathrm{H}$ NMR 
$\left(\mathrm{CDCl}_{3}, 300 \mathrm{MHz}\right) \delta 7.87(\mathrm{bs}, 1 \mathrm{H}), 7.53(\mathrm{~m}, 2 \mathrm{H}), 7.43(\mathrm{~m}, 2 \mathrm{H}), 7.32(\mathrm{~m}, 1 \mathrm{H}), 7.01(\mathrm{~s}, 1 \mathrm{H}), 6.89(\mathrm{~s}, 1 \mathrm{H})$, $3.97(\mathrm{~s}, 3 \mathrm{H}), 3.93(\mathrm{~s}, 3 \mathrm{H}), 2.45(\mathrm{~s}, 3 \mathrm{H}) ;{ }^{13} \mathrm{C} \mathrm{NMR}\left(\mathrm{CDCl}_{3}, 75 \mathrm{MHz}\right) \delta 147.3,145.0,133.6,132.8,130.2$, 128.9, 127.4, 126.9, 122.9, 108.6, 100.8, 94.4, 56.6, 56.4, 10.3; IR $\left(\mathrm{CDCl}_{3}, \mathrm{~cm}^{-1}\right) 3749,3691,1482,1243$, 1216, 1000, 722; HRMS calc : 267.1259; found : 267.1245 .

\section{2,3-Dimethyl-1H-indole (Table 2, entry 5). ${ }^{6}$}

General procedure A was followed at $50 ; \mathrm{C}$ with 6.0 equiv of ketone. Column chromatography over silica gel eluting with 1:3 ethyl acetate:hexanes gave $103 \mathrm{mg}(71 \%)$ of the title compound as a off white solid. Melting point and spectral data are identical to those previously described.

\section{3,6-Dimethyl-2-phenyl-1H-indole (Table 2, entry 6).}

General procedure $\mathrm{A}$ was followed at $50 \mathrm{i} \mathrm{C}$ with 1.1 equiv of ketone and 2.0 equiv of $\mathrm{K}_{3} \mathrm{PO}_{4}$. Column chromatography over silica gel eluting with 5:95 ethyl acetate:hexanes gave $198 \mathrm{mg}(90 \%)$ of the title compound as an off white solid: $\mathrm{mp}=122-124{ }^{\circ} \mathrm{C} ;{ }^{1} \mathrm{H} \mathrm{NMR}\left(\mathrm{CDCl}_{3}, 300 \mathrm{MHz}\right) \delta 7.88(\mathrm{bs}, 1 \mathrm{H}), 7.58(\mathrm{~m}$, 2H), $7.51(\mathrm{~m}, 3 \mathrm{H}), 7.37(\mathrm{~m}, 1 \mathrm{H}), 7.17(\mathrm{bs}, 1 \mathrm{H}), 7.02(\mathrm{~m}, 1 \mathrm{H}), 2.53(\mathrm{~s}, 3 \mathrm{H}), 2.50(\mathrm{~s}, 3 \mathrm{H}) ;{ }^{13} \mathrm{C} \mathrm{NMR}\left(\mathrm{CDCl}_{3}\right.$, $75 \mathrm{MHz}) \delta 136.3,133.6,133.4,132.3,128.9,128.0,127.7,127.2,121.4 .188 .8,110.8,108.7,22.1,10.1$; IR $\left(\mathrm{CDCl}_{3}, \mathrm{~cm}^{-1}\right)$ 3464, 2923, 1461, 1034, 1007, 733, 698; HRMS calc : 221.1204; found : 221.1207.

\section{2,3-Dimethyl-6-trifluoromethyl-1H-indole (Table 2, entry 7).}

General procedure B was followed at $50 ¡ \mathrm{C}$ with 6.0 equiv of ketone. Column chromatography over silica gel eluting with 5:95 ethyl acetate:hexanes gave $108 \mathrm{mg}(51 \%)$ of the title compound as a yellow solid: mp $=156-157{ }^{\circ} \mathrm{C} ;{ }^{1} \mathrm{H}$ NMR $\left(\mathrm{CDCl}_{3}, 300 \mathrm{MHz}\right) \delta 7.85(\mathrm{bs}, 1 \mathrm{H}), 7.53(\mathrm{~m}, 2 \mathrm{H}), 7.33(\mathrm{~m}, 1 \mathrm{H}), 2.42(\mathrm{~s}, 3 \mathrm{H}), 2.27$ $(\mathrm{s}, 3 \mathrm{H}) ;{ }^{13} \mathrm{C} \mathrm{NMR}\left(\mathrm{CDCl}_{3}, 75 \mathrm{MHz}\right) \delta 134.0,131.7,127.4,123.8,123.0,122.6,118.2,115.8(\mathrm{~m}), 107.5(\mathrm{~m})$, 11.9, 8.7; IR $\left(\mathrm{CDCl}_{3}, \mathrm{~cm}^{-1}\right)$ 3409, 2925, 2865, 1426, 1331, 1275, 1160, 1150, 1108, 874, 820; Anal. Calcd for $\mathrm{C}_{11} \mathrm{H}_{10} \mathrm{~F}_{3} \mathrm{~N}$ : C, 61.97; H, 4.73; Found: C, 61.99; H, 4.78.

\section{2-Bromo-4,5-dimethoxy-nitrobenzene. ${ }^{7}$}

The procedure used is adjusted from that reported in the literature. A $250 \mathrm{~mL}$ round bottom flask equipped with a magnetic stir bar was charged with bromoveratrole $(3 \mathrm{~mL}, 20.86 \mathrm{mmol})$ and glacial acetic acid ( 5 $\mathrm{mL})$. This stirring mixture was cooled to between $-4^{\circ}$ and $-8^{\circ} \mathrm{C}$, then fuming nitric acid $(1.77 \mathrm{~mL}, 41.71$ mmol) was added dropwise. When addition was complete, the reaction mixture was allowed to warm to room temperature, then stirred at this temperature for an additional $30 \mathrm{~min}$. Water $(50 \mathrm{~mL})$ was then added to the reaction and the resulting precipitate was collected by filtration and recrystalized from ethanol to give $4.16 \mathrm{~g}(76 \%)$ of the title compound as light yellow needles. Melting point and spectral data are identical to those previously described.

\footnotetext{
${ }^{6}$ Raucher, S.; Koolpe, G. A. J. Org. Chem. 1983, 48, 2066.
} 
- S10 -

${ }^{7}$ Dillard, R. D.; Yen, T. T.; Stark, P.; Pavey, D. E. J. Med. Chem. 1980, 23(7), 717. 